\title{
PERFORMANCE IMPROVEMENT DISTRICT BELINYU GUARD PT.TIMAH IN THE PRESENCE OF GIVING BONUS COMPENSATION
}

\author{
Edwin Trigunawan 1), Erwin Sugianto 2) \\ Department of Management, Faculty of Economics, University of Bangka Belitung, Bangka, Bangka Belitung, Indonesia \\ Email correspondence: Edwintrigunawan140698@gmail.com
}

\begin{abstract}
The purpose of this study is the first one to know is there an increase in the performance of the security guard with their bonuses PT.Timah compensation, the latter in order to give an idea of the performance of the security PT.Timah so as to provide input to the leading companies in making decisions regarding performance improvement and compensation in accordance with the expectations of the workers. This research method is descriptive and qualitative analysis. Resource persons from this study were drawn at random from among the guard PT.Timah, with the number of respondents as many as 10 people. The results obtained from this study is the performance of a high enough security PT.Timah although bonus compensation given by the company is not as expected the guards,
\end{abstract}

Keywords: Compensation, performance bonuses.

\section{Introduction}

People work one goal is to get compensation from the job he is doing, and therefore the additional compensation is often called the bonus is expected to improve the performance of employees / workers, of which the bonus will be given to the worker if the worker does the work more than the standard that has been The specified company. compensation is defined as the amount of money or awards granted by an organization or a company to its employees, as payment for its services in performing duties, obligations and responsibilities imposed upon him.(Muljani, 2002)

In this present era every company would want to improve the performance of its employees, in various ways by the company for improving the performance of employees in order to achieve the company's goals, one of them with the provision of compensation to employees who have worked to the maximum. Human resources is an important part in achieving the goals of the company, therefore the quality of performance is very important for the company. The purpose of this study is to see is there any influence of granting compensation to increase security performance PT. Tin Belinyu subdistrict region. With the research is expected to help the leadership of the company in decision making.

Performance can be defined as the ability of a person to complete the work on their own, but in principle the performance of the process of achieving results. Hamel and Prahalad (1994). They say "if you do not measure it, you can not improve it". The purpose of this statement is a performance measurement is an important variable in the management as part of an effort to improve the performance itself. Without measurement of performance is impossible for a manager can determine the development of the company that manages and certainly, whenever considered necessary, they also could not improve the performance.(Basic, 2014), Performance is synonymous with performance and with the performance then will be able to determine the performance, so it can be defined that the performance is the quality and quantity of the work accomplished by the employees / workers in carrying out the duties and responsibilities that have been given to him.(Selvia, 2014)

In the current era of globalization is increasing and the price needs to meet the needs of the increasingly expensive. This makes the lack of compensation would affect the performance of the employee / worker. With these conditions expected workers would be issued if the company giving out the best performance bonus compensation for his work. 


\section{Literature review}

Performance is the behavior that a person in real produce work performance in accordance with its role in an agency. Objective assessment of performance by Vaithzal Rival (2003: 312) basically include:

1. Seeing the employee's performance for some time backward

2. So that salaries can be appropriate, for example, raises, bonuses

3. So that employees can be liable

4. Can be used as a differentiator among employees

5. For human resource development.

A. Procurement movement, rotation, or transfer employees

B. Position increased

C. conduct training

Compensation management is the application of the compensation system can help an agency to achieve their end and also maintain the necessary people and to improve their motivation and commitment.

The same thing was stated Ivancevich (1995), "compensation is a function

Human Resource Management (HRM) associated with each type of reward received by individuals in response to the execution of organizational tasks.(Philosophy, nd), According Simamora (1997) consists of compensation Financial compensation (principal payment, payment achievement, incentive pay, paid toughest, program protection, paid outside of working hours, facilities) and non-financial compensation (work and working environment).(Firmandari, 2014)

Mondy and Noe (2008: 374) divides into two parts, namely compensation

direct financial compensation consists of salaries, wages, and incentives (commissions and bonuses). And indirect financial compensation in the form of a wide range of facilities and benefits.

a. Salary.

Salary is the financial reward paid to employees on a regular basis, such as annual, quarterly, monthly or weekly.

b. Wage

Wages represent a direct financial reward paid to employees based on hours worked, the number of goods produced or the number of services provided.

c. Incentive

Incentives are direct remuneration paid to employees for exceeding performance standards specified.(Trakindo, Samarinda, and Fauzi, 2014)

No form of compensation in the form of money and there is no form of money, usually in the form of wage compensation in the form of money and its value is not fixed can fluctuate depending on the economic level in Indonesia. Where are we now know is the value of the rupiah is not stable.

\section{Research methods}

In conducting this research method used is the interview system namely by asking a few brief questions to several speakers, speaker of the study was a security guard Belinyu PT.Timah subdistrict. Selection sempel done randomly. Total sample of this research were 10 respondents. This type of research is descriptive research analysis.

Data used in this research is the primary data, ie data obtained directly from the source (without going through intermediaries) and data gathered from the answers to the questions made and according to the researchers.

\section{Finding and discussion}

a) Compensation

Based on the interviews showed that the salary received by a security guard PT.Timah been as expected, is the salary here is only the basic salary received by a security guard PT.Timah not include other bonuses, and the number of overall salary according to sources was enough as expected. The salary gap between the inside of the company is perceived by the guards very inappropriate or unfair to say this is what enviable inside the guards, and also a bonus given by a resource company less in accordance with the specified overtime. Social security given is also very inconsistent with that expected by the speaker, accident insurance is the same, and also fulfilling the needs and facility employees is less appropriate or less appropriate according to the sources.

b) performance 
The interview with questions relating to the performance of the results obtained in implementing job security enthusiastic high enough, they are also willing to be placed anywhere, is a regular in his habits PT.Timah security guard stationed in various regions of the Pacific Islands in the Pacific region, especially the task is often called task "Tasir" in which a security guard bebagai PT.Timah placed in the area to maintain the security of tin and valuable inventory for companies PT.Timah.dan also in the world of work is no such thing security guard shift change, they perform a shift change in accordance with time has been established, in carrying out their duties the guards have carried out with high responsibility.

\section{Conclusion}

Based on the analysis and discussion about the influence of bonus compensation for the performance of security PT.Timah can be concluded that although the bonus given the company less as expected, the performance shown the guards can be quite high, because, although the bonus does not match expectations but other compensation such as salary and benefits has been as expected by the guards.

\section{Suggestion}

Researchers suggested to the leadership of PT.Timah to further increase the bonus granted in accordance with the occupational hazards of the tasks assigned, and also pay more attention to work safety assurance and fulfillment and security facilities so that they can work more optimally again.

\section{Bibliography}

Basic, K. (2014). Basic Concepts of Performance and Performance Management, 1-67.

Firmandari, N. (2014). Compensation Effect on Employee Performance With Work Motivation For Variable Moderation (Studies in Bank Syariah Mandiri Branch Office Yogyakarta). Ekbisi, IX (1), 25-34.

Muljani, N. (2002). Compensation As Motivator To Improve The Performance Of Employees | Muljani | Journal Of Management And Entrepreneurship. Journal Of Management \& Entrepreneurship, 4 (2), 108-122. Https://Doi.Org/Https://Doi.Org/10.9744/Jmk.4.2.Pp.\%20108-122

Selvia, M. (2014). Effect Of Motivation, Discipline Work And Work Environment On Employee Performance PT. General Yaja Steel Core Semarang. Retrieved From Http://Mahasiswa.Dinus.Ac.Id/Docs/Skripsi/Jurnal/14306.Pdf

Trakindo, PT, Samarinda, U., \& Fauzi, U. (2014). Compensation Effect on the Performance of Employees In. Main Trakindo Samarinda, (3), 172-185. 